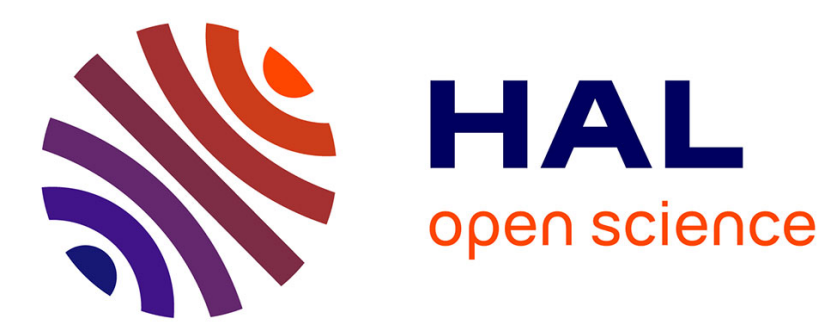

\title{
Dam and levee failures: an overview of flood wave propagation modeling
}

André Paquier, N. Goutal

\section{To cite this version:}

André Paquier, N. Goutal. Dam and levee failures: an overview of flood wave propagation modeling. La Houille Blanche - Revue internationale de l'eau, 2016, 1, pp.5-12. hal-01393284

\section{HAL Id: hal-01393284 \\ https://hal.science/hal-01393284}

Submitted on 7 Nov 2016

HAL is a multi-disciplinary open access archive for the deposit and dissemination of scientific research documents, whether they are published or not. The documents may come from teaching and research institutions in France or abroad, or from public or private research centers.
L'archive ouverte pluridisciplinaire HAL, est destinée au dépôt et à la diffusion de documents scientifiques de niveau recherche, publiés ou non, émanant des établissements d'enseignement et de recherche français ou étrangers, des laboratoires publics ou privés. 


\title{
Dam and levee failures: an overview of flood wave propagation modeling
}

\author{
André PAQUIER ${ }^{1}$, Nicole GOUTAL ${ }^{2}$
}

${ }^{1}$ Irstea, UR HHLY, andre.paquier@irstea.fr

2. $E D F R \& D$, Laboratoire d'hydraulique Saint-Venant, nicole.goutal@edffr

\begin{abstract}
Dams and levees are hydraulic structures that are designed to resist to water pressure, but they occasionally break because of constructional defaults or unexpected events. When such a failure occurs, water can be suddenly released and create a flood wave more dangerous than natural events. Hydrodynamic modelling of such waves includes both estimating the flow hydrograph at the structure site and propagating the latter hydrograph downstream the structure. For engineering purposes, simplified erosion models are used to obtain the breach hydrograph for earthen embankments while instantaneous failure is often assumed for concrete structures. For flood wave propagation, 1-D or 2-D shallow water equations are solved using numerical schemes that can deal with supercritical and subcritical flow regimes. Uncertainty is likely to be high because it is difficult to calibrate the numerical model for flows much stronger than actual observations. Particularly, because of high velocities, sediment transport is likely to occur and to modify the risk parameters; numerical modelling can help defining the range of uncertainty due to this sediment transport but calibration is even more difficult than for hydrodynamic modelling. The description of these latter models is illustrated on various events, the Malpasset dam failure that occurred in 1959 during the first filling, the 100 year flood in Agly coastal plain that resulted in levee breaching in 1999 and the Ha! Ha! dam failure that caused huge geomorphological changes along the downstream valley.
\end{abstract}

Key-words: numerical modelling, emergency planning, risk analysis, uncertainty estimate

\section{Ruptures de barrages et de digues : une revue de la modélisation de la propagation de l'onde de submersion}

\begin{abstract}
RÉSUMÉ. - Les barrages et les digues sont des ouvrages hydrauliques conçus pour résister à la pression de l'eau mais ils peuvent se rompre suite à des défauts de construction ou à des événements inattendus. Quand une telle rupture intervient, l'eau est soudainement relâchée et peut créer une onde de submersion plus dangereuse que les crues naturelles. La modélisation hydrodynamique de telles ondes comprend à la fois l'estimation de l'hydrogramme sur le site de l'ouvrage et la propagation de cet hydrogramme à l'aval de l'ouvrage. Dans le cadre de l'ingénierie, des modèles d'érosion simplifiés sont utilisés pour obtenir l'hydrogramme de rupture de remblais en terre alors qu'une rupture instantanée est prise en compte pour des ouvrages en béton. Pour la propagation de l'onde de rupture, les équations de Saint Venant 1D ou 2D sont résolues par des schémas numériques qui considèrent à la fois les régimes fluvial et torrentiel et la transition de l'un à l'autre. L'incertitude est souvent forte à cause d'un calage sur des observations pour des écoulements bien plus faibles que ceux modélisés lors de ces études. En particulier, à cause des fortes vitesses lors d'une onde de rupture, un fort transport de sédiments peut se produire et modifier les caractéristiques de l'onde et donc les paramètres du risque ; la modélisation numérique de ce transport peut aider à réduire l'intervalle d'incertitude mais le calage du modèle sera encore plus compliqué que pour un modèle d'écoulement. Pour tous ces modèles, la description fournie est accompagnée d'exemples d'utilisation illustrant les potentialités des modèles utilisés. Parmi ces exemples, on trouve la rupture du barrage de Malpasset qui a eu lieu en 1959 lors du premier remplissage, la crue centennale de 1999 dans la basse plaine de l'Agly accompagnée d'une rupture de digue et la rupture du barrage Ha !Ha ! qui a causé en 1996 d'énormes changements dans la morphologie de la vallée.
\end{abstract}

Mots-clés : modélisation numérique, plans particuliers d'intervention, analyse du risque, estimation de l'incertitude

\section{INTRODUCTION}

Dams and levees are hydraulic structures that are storing water for short or long periods. Although they are designed to resist to water pressure, they occasionally break because either design constraints were underestimated or constructional defaults weaken the structure resistance. When such a failure occurs, water can be suddenly released and then the high flow velocities are an essential factor for risk assessment.
For engineering purposes, hydraulic modelling of the consequences of such failures is divided into two steps: first, evaluating the causes of the failure and estimating the flow hydrograph at the structure site; second, calculating the flood wave propagation downstream the structure. Modelling tools often merge the two steps into one single run that aims at calculating flow parameters both upstream and downstream the structure and flow discharge hydrograph at the structure site using simplified failure hypothesis and the upstream and downstream water elevations. 
For the flow discharge estimate at dam site, progressive breaching will be considered for earthen embankments while other structures will generally be considered to collapse instantaneously.

\section{FLOOD WAVE PROPAGATION}

\section{II.1. Software for dam-break wave simulation}

The first European law on dam-break risk analysis was presented in France in 1968, following the 1959 Malpasset dam-break which was responsible for more than 400 injuries. The decree makes it compulsory for the owners of the largest dams to set up emergency plans, including a simulation of the would-be flood wave, along with maps showing flooded areas and wave arrival times.

EDF R\&D and IRSTEA have had a lot of experience with dam-break modelling: in the mid 60's, work started at the lab to develop industrial numerical tools for the prediction of dam break flood waves, and the first studies to fulfil the legal requirements were delivered in the early 1970's; since then calculations for about 100 dam-breaks have been made by EDR R\&D in France.

These studies are complex because of the geometry (steep bed-slopes, important section variations), wave propagation over dry areas downstream the dam, presence of other dams downstream which may break or not, and tributaries. Furthermore, some of the studies need a two dimensional treatment (for instance, when a river reaches a coastal plain). These particularities lead to a very fast flow propagation over dry areas with important transitions between supercritical and subcritical flows.

This paragraph deals with the numerical developments done on 1D and 2D software in the 1990's.

First of all, all of the codes attempt to solve the Shallow Water Equations for dam-break situations. The question is to whether such equations are appropriate for use under all aspects of dam-break flow has been raised but with few alternatives offered at present. Furthermore, it can be concluded that the Shallow Water Equations allow for an accuracy which is 'acceptable' with respect to:

- the general objectives of dam-break simulation (i.e. prediction of maximum water levels and wave arrival times), at least as far as pure hydrodynamics are concerned and providing relevant numerical scheme is used.

- the uncertainties of the data: topography, initial conditions etc.

These points will be illustrated in the next paragraph.

Secondly, the numerical scheme for solving Shallow-Water equations must handle properly with fast unsteady flow, jumps and dry areas. More precisely, the scheme must be conservative and respect the positivity of the water depth due to the wetting-drying areas.

In the 1960's, the first industrial code was based on a shock fitting numerical scheme with finite difference space discretization. In the 1990's, all the industrial software have taken advantage of the progress of numerical scheme for hyperbolic system with source terms. Most of the industrial software (MASCARET - TELEMAC - RUBAR etc) used explicit finite Godunov finite volume scheme [Ata et al., 2010; Audusse et al., 2000; Goutal et Maurel, 2002; Goutal et Sainte-Marie, 2010; Paquier, 1995]. More recently, in the academic teams, many works have been done to obtain numerical schemes which are very efficient: conservative, positive and respect the non-trivial equilibrium. A special attention has been paid to the treatment of source terms to keep a lake at rest [Goutal et Maurel, 2002]. All these properties are essential to deal with dam-break wave simulation. But from an operational point of view, the industrial software must have the capabilities to deal with more difficulties: the singularities as dams, reservoirs along the valley. These dams can collapse or resist when the wave arrives. Fig. 1 illustrates quite well the complexity of a real study: $300 \mathrm{~km}$ of length and many dams located along the valley.

Moreover, in the frame of 1D simulation, junctions of two rivers have to be treated in order to model storage of water in the tributary, release with a time delay for real cases of dam break wave. To solve this problem, a simplified 1D-2D coupling is used (see schematic case in the next paragraph). From a schematic point of view, the 1D domain is composed by three reaches joining at the confluence. Two of them form the main valley and the last one is the tributary.

\section{II.2. Validation}

At the beginning of the 1990's, due to the progress on numerical scheme as mentioned in the previous paragraph, numerical methods and computational hardware are more advanced than those available during the early eighties. This allows the model of today to simulate dam-break conditions more reliably and more user friendly tools to be developed. Nevertheless, an important work of validation was needed to assess the relevance of the software to produce reliable results for risk analysis because for such a flow, the calibration is not conceivable due to the lack of available data.

In this context, a European concerted action CADAM [Proceedings of the first CADAM workshop, 1998; Proceedings of the final CADAM workshop, 1999] was promoted in order to offer a framework within which the performance of different numerical modelling scheme may be assessed against analytical test case and schematic physical modelling and a study programme running for a duration of 2 years from February 1998. The programme is funded by the European Commission and has the following aims:

- to develop the exchange of information between participants (universities, research organisations, industry),

- to promote the comparison of numerical dam-break models and modelling procedures with analytical, experimental and field data,

- to promote the comparison and validation of software packages developed or used by the participants,

- to define and promote co-operative research.

The first meeting was held in EDF-R\&D and proposed analytical test cases and up to now the proceedings are considered as a reference for validation.

\section{II.2.1. Schematical test-case}

The third meeting of the working group on dam-break modelling was hosted by UCL Louvain-la-Neuve and ULB Chatelet, Belgium, June [Proceedings of the first CADAM workshop, 1998]. Experimental data obtained on a laboratory test facility combining a square-shaped upstream reservoir and a L-shaped channel were used for comparison with computation results from 8 research teams.

The channel is made of a 3.87 and a $2.92 \mathrm{~m}$-long and $0.495 \mathrm{~m}$-wide rectilinear reaches connected at right angle by a $0.495 \times 0.495 \mathrm{~m}$ square element (Fig. 2). The channel slope is equal to zero. A guillotine-type gate connects this L-shaped channel to a $2.44 \times 2.39 \mathrm{~m}$ square reservoir. 


\section{Numerical simulation of the Bort-les-Orgues dam-brake wave Water level time evolution}

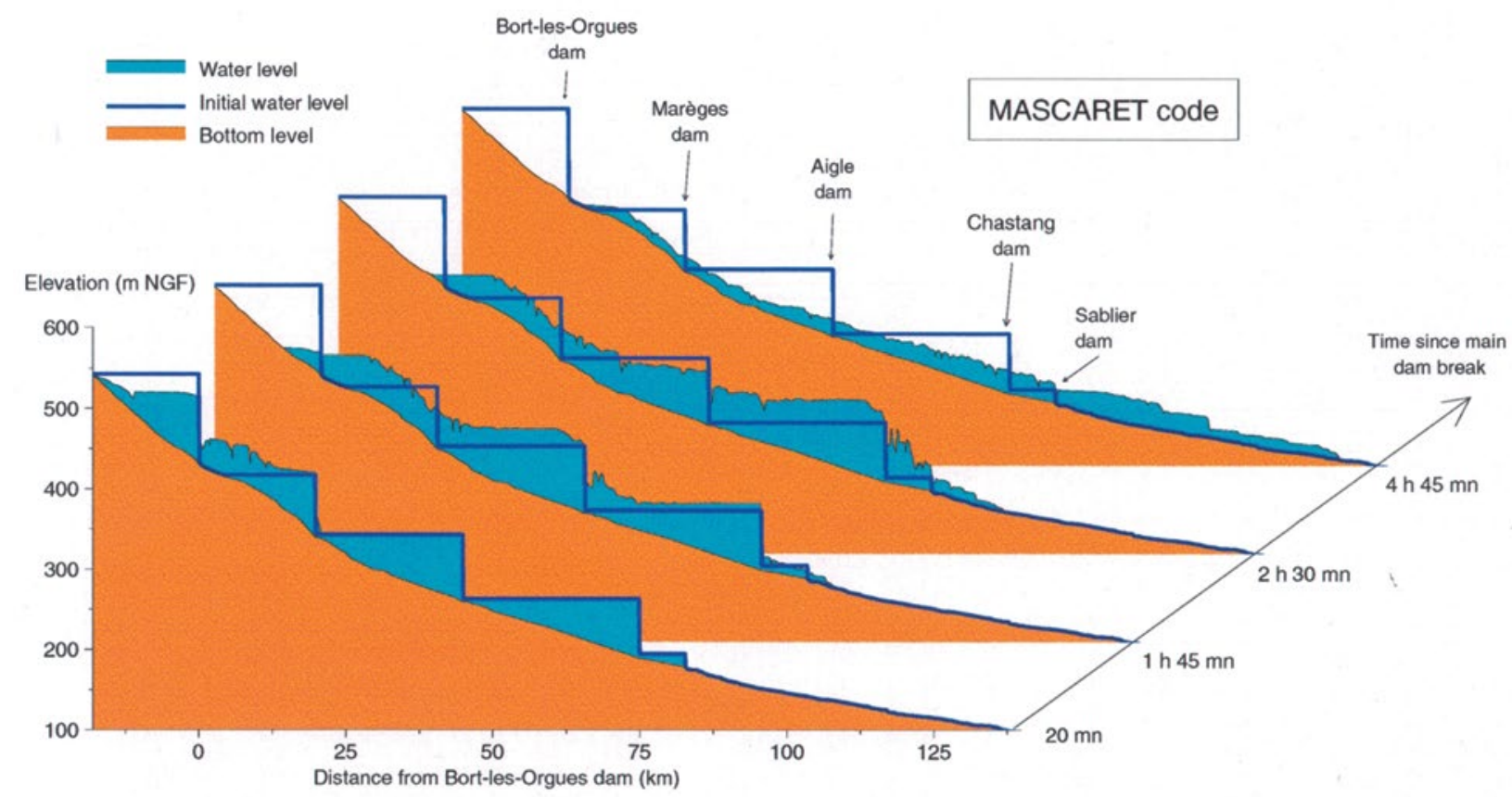

Figure 1: Real dam break wave simulation.
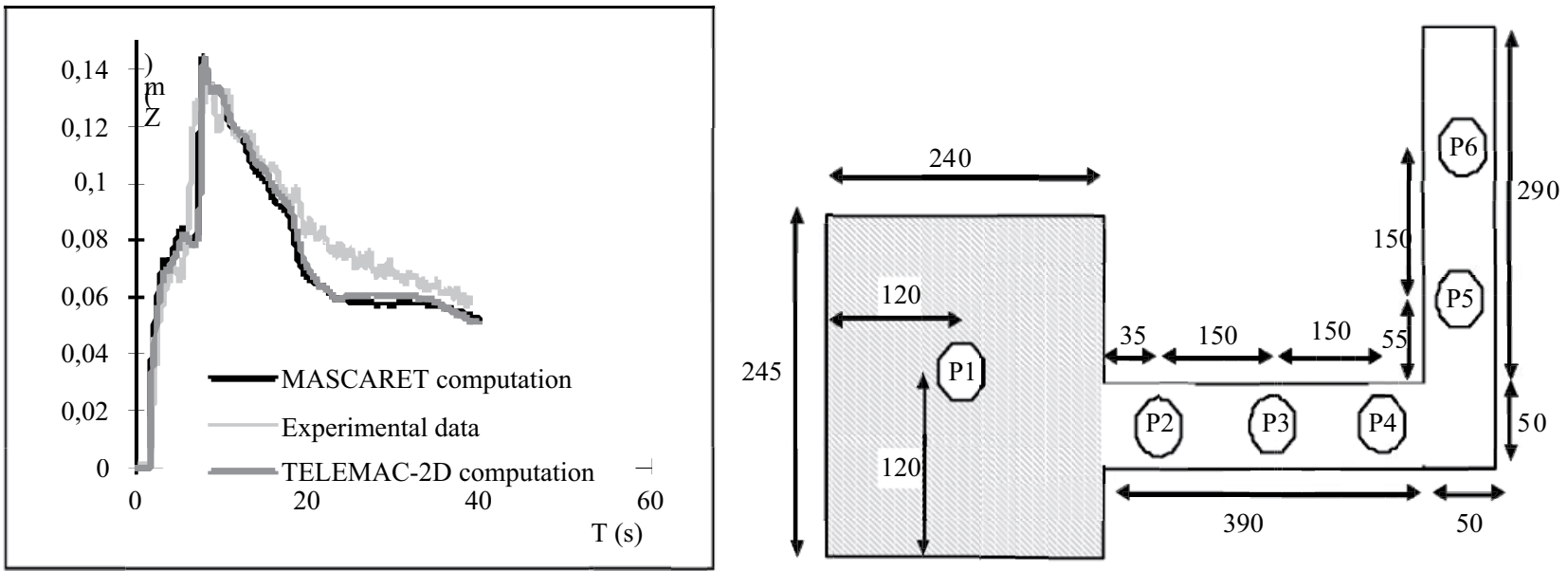

Figure 2: UCL test-case: L-shaped channel. a. Example of results at one gauge using $1 D / 2 D$ coupling for the corner for MASCARET. $b$. Geometry of the channel and position of the gauging points.

Water is initially at rest in the upstream reservoir, with the free surface $20 \mathrm{~cm}$ above the channel bed level. Initial water depth in the channel is zero for the dry-bed test and $1 \mathrm{~cm}$ for the wet-bed test. The downstream boundary is a chute.

The Manning coefficients evaluated through steady-state flow experimentation are 0.0095 and $0.0195 \mathrm{~s} / \mathrm{m} 1 / 3$ respectively for the bed and the walls of the channel.

The experimental results consist in water level at $0.5 \mathrm{~s}$ intervals for six gauging points, during $40 \mathrm{~s}$. The flow is essentially two-dimensional in the reservoir and at the angle between two reaches of the L-shaped channel. However, it is mostly one-dimensional in both rectilinear reaches.

On this case, most of the computations were able to reproduce the damping effect of the corner and the upstreammoving hydraulic jump which forms at the corner (Fig. 2).

\section{II.2.2. Malpasset Dam-break wave simulation}

The Malpasset Dam was built for irrigation and the storage of drinking water. It was located in a narrow gorge of 
the Reyran river valley, in the Departement of Var, approximately $12 \mathrm{~km}$ upstream of Frejus on the French Riviera. The dam was a double curvature arch dam of $66.5 \mathrm{~m}$ maximum height, with a crest length of $223 \mathrm{~m}$. The maximum reservoir capacity was meant to be $55106 \mathrm{~m}^{3}$ however the dam failed explosively at night in December 1959 - more precisely at 21:14 on 2 nd December. The filling of the reservoir had first been very slow, but the last $4 \mathrm{~m}$ had been filled in 3 days, because of exceptionally heavy rain in the preceding days. To cope with the flood, the bottom outlet gate had been opened at 18:00 to control the rising reservoir. The flood wave ran along the Reyran valley to Frejus. A total of 433 casualties were reported.

Little of the dam arch remained, and a deep trough was cut through the rock foundations on the left bank. $1.5 \mathrm{~km}$ downstream, a $800 \mathrm{~m}$ portion of the Esterel freeway and a bridge were destroyed. Huge blocks were carried out and deposited downstream. Trace marks of the flood wave show that the flood rose to a level as high as $20 \mathrm{~m}$ above the original bed level.

The main field data are:

- Propagation times of the flood wave. 3 electric transformers were destroyed by the wave and the exact times of these shutdowns are known. The transformers are denoted A, B and $\mathrm{C}$ and their location is shown in Fig. 3 and shut down times are given explicitly in Table 1. Since transformer A was in the bottom of the valley, the shutdown time here is the wave arrival time. For the other two transformers (B \& C), the shutdown time is probably somewhere between the wave arrival time and the time of peak water level.

- A survey was done by the local police that shows the high water marks on both the left and right banks. Nearly 100 points along the banks have been surveyed.

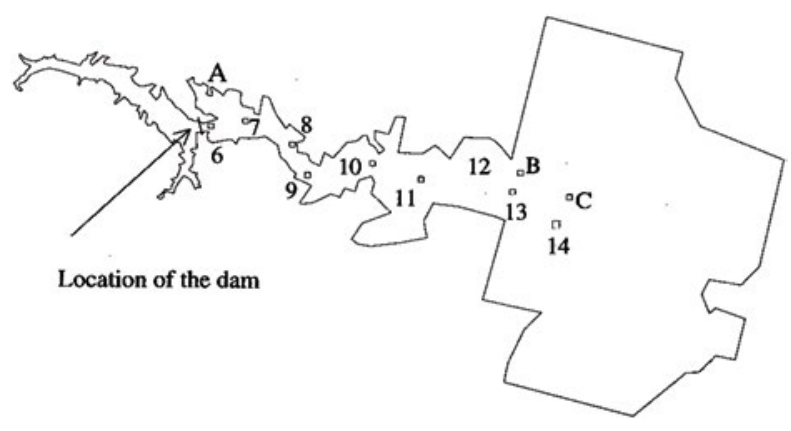

Figure 3: Malpasset case: location of the gauges and electric transformers in the computation domain.
A non-distorted 1/400 scale model was built in our laboratory in 1964 and was calibrated against observations. At that time, the Strickler coefficient $K$ of the valley was estimated to be in the range 30-40. Fourteen gauges were put in the physical model, the first 5 being in the reservoir itself (Fig. 3). The maximum free surface elevation at these gauges was measured. The measurements from these gauges are in a good agreement with the observed high water marks.

The comparison of 1D and 2D simulations [Ata et al., 2010; Proceedings of the final CADAM workshop, 1999] against the field data illustrates quite well the relevance of shallow-water equations to propagate dam-break wave (Fig. 4, Fig. 5) For such a problem with large uncertainties, the full Navier-Stokes equations are not required.

\section{BREACHING}

Levee breaching is quite different from dam failure because generally the head between the upstream and downstream sides is much lower and the flow pattern around the structure is generally more complex (Fig. 6).

\section{III.1. Simulating breaching}

Dam break wave is essentially due to the emptying of a reservoir in the valley downstream. This emptying will be more or less rapid depending of the type of dam failure and the dimensions of the breach. For vault dams, the failure can be instantaneous and involve a large part of the dam, which implies the worse consequences downstream; conversely, an earthen dam will be progressively eroded and the breach is likely to develop on a small part of the dam. However, the breach development is generally short if compared to the wave propagation time. Thus, far from the dam, the flood parameters essentially depend on the volume of the reservoir, the height of the dam and the propagation parameters of the valley (slope, dimensions, land use,).

In case of levee breaching, the water elevation upstream the levee depends either on the sea level or on the river level, which may vary rapidly with time. Thus both the starting time of breaching (and thus the duration of breach development) and the dimensions of the breach are essential parameters that influence the flow discharge to the flood plain. Because most of the levees are embankments made of earth and/or rocks, progressive failure should often be considered. The location of the breach is also a question to be solved. Depending of the type of breach (for instance, piping or overtopping), the pressure (mainly determined by the head between upstream and downstream) or the velocity over the downstream side of the levee are the risk factors to be compared with the resistance of the levee; generally, the breach will open at a location in which a high risk factor is combined to a weak resistance: such locations often do not

Table 1: Dam-break wave simulation time (in seconds)

\begin{tabular}{|c|c|c|c|c|}
\hline Transformer & Shutdown time & $\begin{array}{c}1 \mathrm{D} \\
K=\mathbf{3 0}\end{array}$ & $\begin{array}{c}2 \mathrm{D} \\
K=\mathbf{3 0}\end{array}$ & $\begin{array}{c}2 \text { 2D } \\
K=35\end{array}$ \\
\hline A & 100 & 91.4 & 98 & 96 \\
\hline B & 1240 & 1221 & 1234 & 1132 \\
\hline $\mathrm{C}$ & 1420 & 1467 & 1358 & 1156 \\
\hline
\end{tabular}


Maximum level

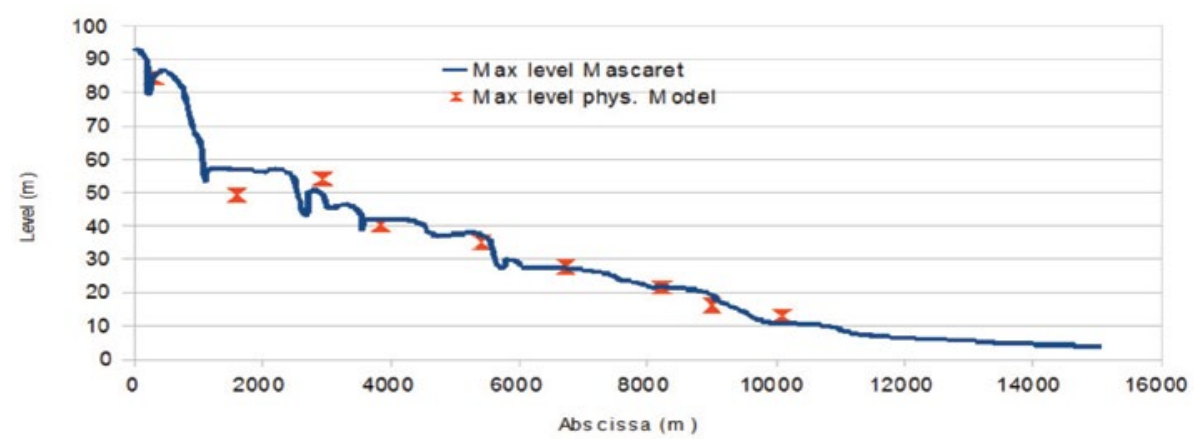

Figure 4: Malpasset case: Maximum water level at the different gauges. 1D simulation-MASCARET software.

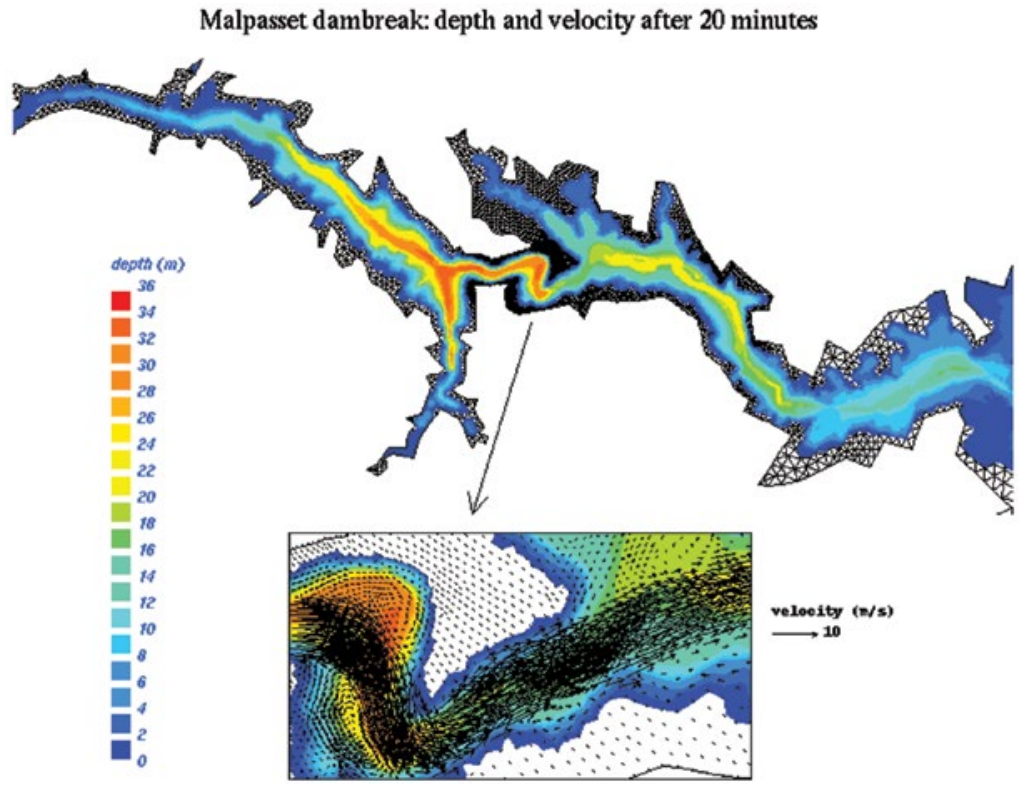

Figure 5: Malpasset case: 2D simulation. TELEMAC 2D.

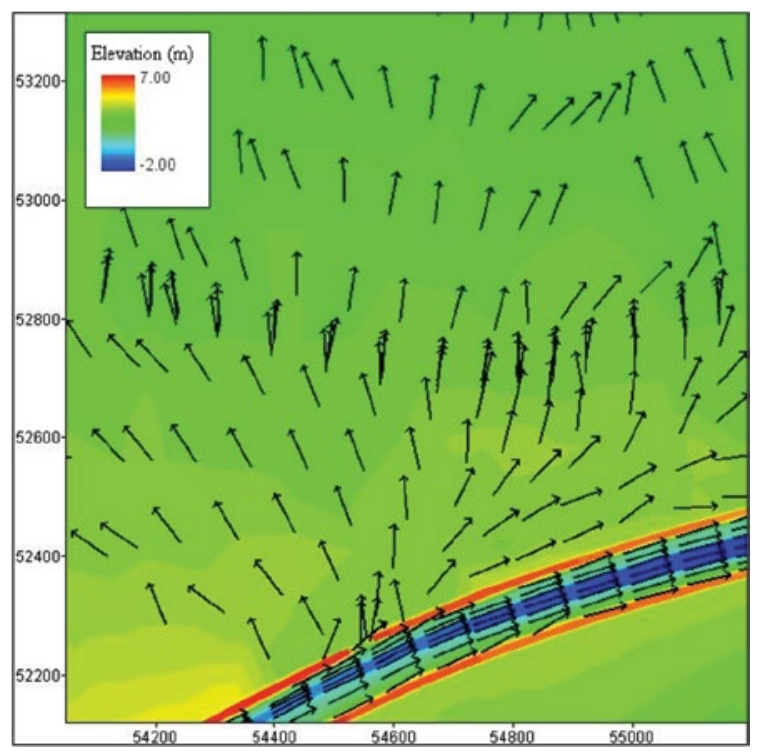

Figure 6: Agly case: Bed elevation and velocity field near a breach. The breach is located $(x=54550, y=52250)$ in the left bank levee (results of 2-D calculation using Rubar 20). change from one event to another one, which explains that historical breach locations should be investigated first.

Various breaching models exist: the key parameter is the erosion rate that directly controls the duration of the breach development [ASCE/EWRI Task Committee on Dam/Levee Breaching, 2011]. Because this latter parameter is difficult to measure and to estimate, the use of a local erosion rate is often replaced by the estimate of a global erosion rate estimated from field or laboratory test or calculated from empirical relations. To simplify beyond, the erosion rate is not estimated and the breach enlargement is directly estimated; this latter approach does not permit to take into account the evolution of the erosion rate with the hydraulic conditions and is often not enough to limit the uncertainty on the downstream wave propagation. To cope with this disadvantage, simplified erosion model was integrated in Renard (from EDF) or Rupro (from Irstea) models: the breach is represented by one (control) cross section of which the geometry evolves following a priori evolution pattern and more or less rapidly depending of the erosion rate. Such models can be used independently to provide the flow hydrograph at breach site and an estimate of the evolution of the breach dimensions [Paquier, 2014]. They can be also integrated in 
software including the calculation of the hydraulic conditions upstream and downstream the embankment and thus avoiding the user to provide these conditions. Depending of the type of structure that fails and the expected accuracy, the corresponding software could solve 1-D shallow water equations (generally for dam break wave) or 2-D shallow water equations (for levees) or perform simplified calculations [Paquier, 2014]. More recently, detailed breach models are developed in order to integrate the whole mechanical processes in both the fluid and solid part of an embankment (for instance, [Brivois, 2005]). They are specific to the type of material and the type of processes during the initiation and development of the breach [Veylon et al., 2013].

\section{III.2. Agly levee case}

Simulating a flood in the Agly flood plain illustrates some difficulties met for levee breaching [Paquier, 2009]. Agly River is separated from the flood plain by two levees between which only a flow of $1500 \mathrm{~m}^{3} / \mathrm{s}$ can be conveyed. Overflow will occur upstream the downstream reach to limit the input discharge but the variations of the downstream conditions (rise of Mediterranean Sea level or accumulation of deposits at the outlet to the sea) can lead to temporary overflow. The location of these overflows will mainly depend on local conditions. Thus, they are more likely to occur in the outside of the bends or upstream the hydraulic structures that cross the river. Then, breaching is expected at the same locations. However, in 1999, a breach occurred [Paquier et al., 2002] at a weak point of the levee in a nearly straight reach (Fig. 6).

In such a case, the development of the breach will depend on the resistance of the levee around the initiation location and the actual available head. This latter head depends on the downstream wave propagation that is likely to maintain a more or less high water elevation: in the Agly case, road embankments prevent the water to flow rapidly to the sea.
Moreover, rainfalls, infiltration below the river levees and overflows on other locations along the levee contribute to a trend of increase of downstream water elevation.

\section{SEDIMENT TRANSPORT}

\section{IV.1. Modelling sediment transport during dam break wave propagation}

Due to the high velocities created by dam failure, the sediment transport capacity is quite high and then volumes of sediment deposited in the downstream valley are such that they can imply a strong rise of peak water elevation (Fig. 7), because the thickness of the deposition layers can be of the same order as the peak water depth (Fig. 8). The origin of the sediments can be the dam materials or can result from the erosion of the valley (either direct erosion of the bed or destabilization of the banks following erosion of their toe). Then, the range of the size of the sediments involved in the transport processes can be quite high from clay to large boulders. If one focus on the deposits, only the coarser part can be taken into account as the finer part settles far downstream or in the reservoirs in which the flow velocity would be quite low. Nevertheless, the usual fining of the sediments from upstream to downstream should be considered to get the right transport parameters along the river.

In order to simulate such transport, for engineering purposes, an equation of sediment mass conservation is added to 1-D or 2-D shallow water equations. The source term of erosion/deposition can be estimated from a deviation either to a sediment transport capacity or to an equilibrium concentration or to a critical bed shear stress. Because of the rapidity of the processes, one should prefer to transfer the calculated erosion or deposition into a geometrical change; for a 1-D model, the erosion or deposition rate is calculated for one cross section, which means that a complementary method

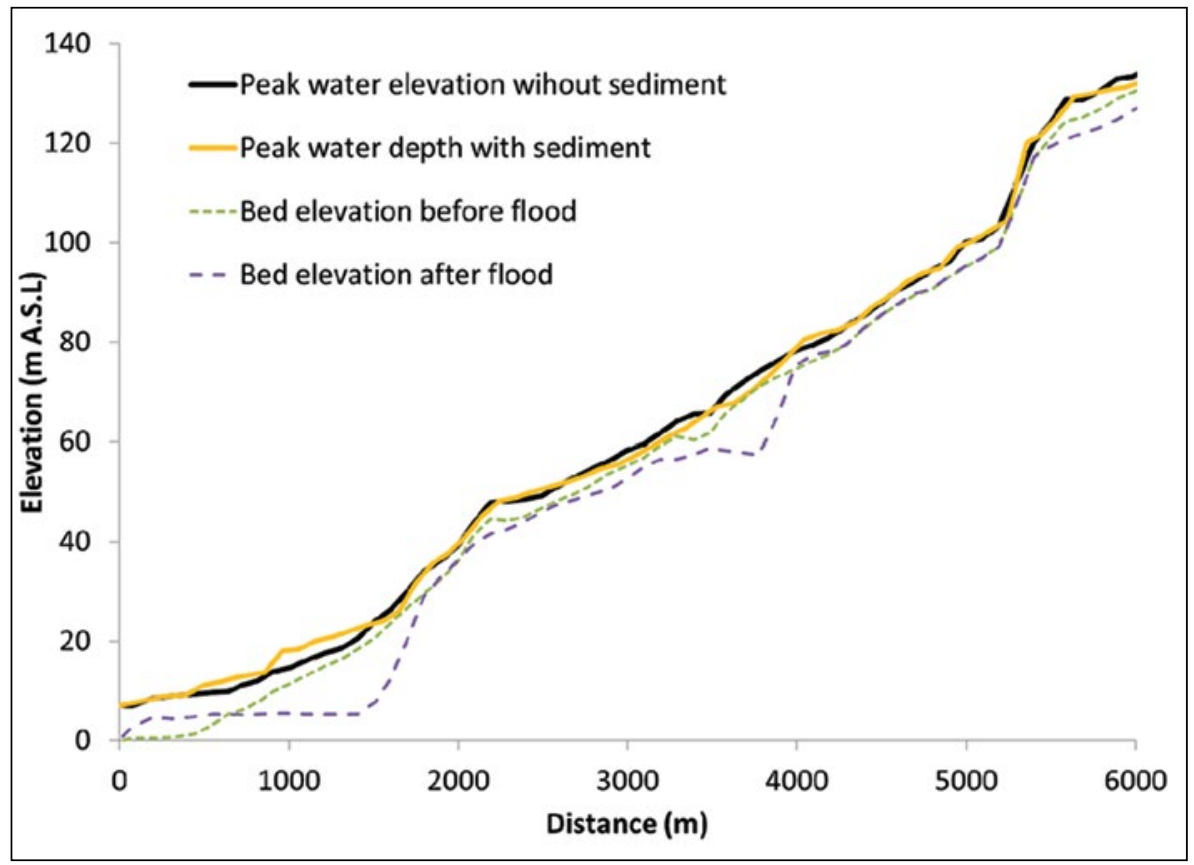

Figure 7: Peak water elevation and bed elevation along the downstream reach of the Ha!Ha! valley. Calculation using RubarBE. 


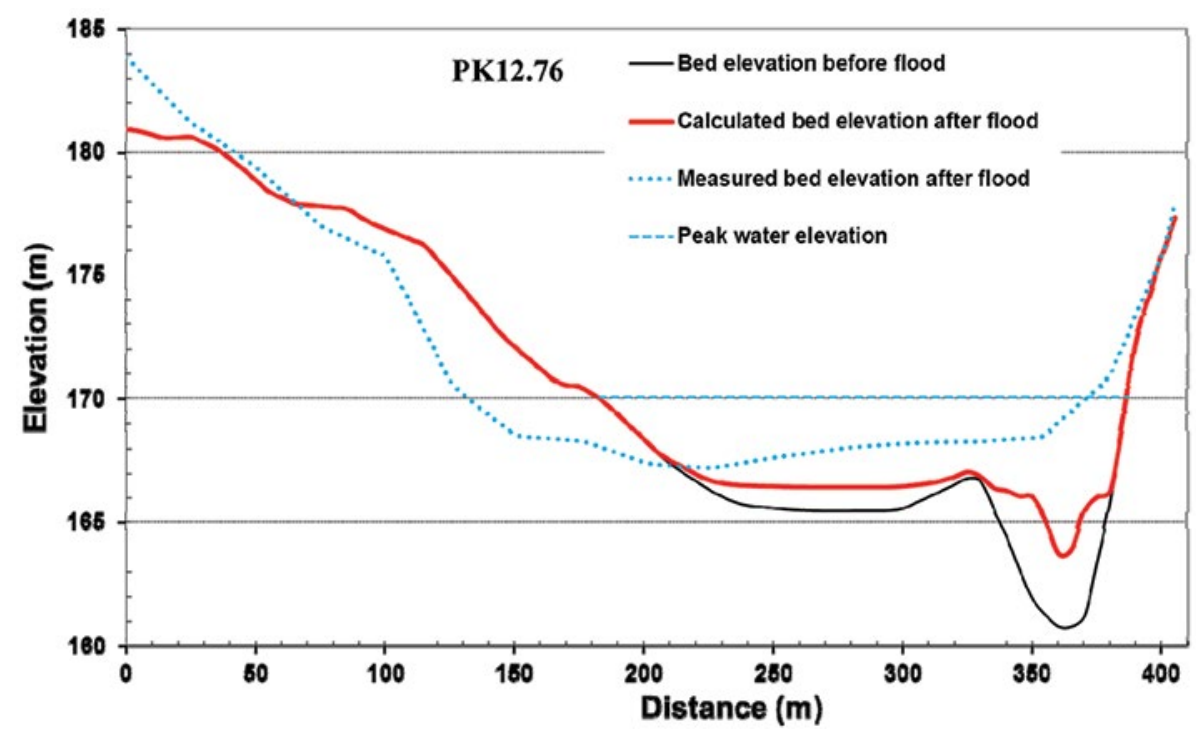

Figure 8: Cross section at a distance of 12760 m from the downstream Ha!Ha! valley. Calculation using RubarBE.

to distribute these changes across the section is required; for instance, in RubarBE model, the distribution depends on the bed shear stress across the section, shear stress estimated using the Merged Perpendicular Method [Khodashenas et Paquier, 1999]. The simpler models include one sediment diameter and one layer; considering several sizes of sediment permit to distinguish between sediments with various behaviours (for instance, bed load and suspended load). In the case of dam break wave, the shear stresses are so high that most part of the sediments are easily transported which means that one typical sediment size (eventually varying along the river and along the time) is often enough; however, because of the high concentrations near the bottom, it can be useful to create a layer containing a mixture of water and sediment with specific properties, this layer being intermediate between the bed sediment layers and the water layer in which concentration of sediments is relatively low and thus that keeps the properties of a water layer. Laboratory experiments of sediment transport immediately downstream a dam failure show that both types of models (one or two layers) can provide relevant results if appropriate numerical methods are used on refined mesh and if a calibration is performed [Soarez Frazao et al., 2012].

For evaluating levee breaching consequences, sediment transport models are also useful either to assess the deposits of the embankment material immediately downstream the breach which can deviate the flow through the breach or conversely to simulate the erosion pit that permits to increase the cross section of the breach [Paquier, 2014].

\section{IV.2. Ha!Ha! dam failure}

The case of the Ha!Ha! dam failure illustrates the influence of sediment transport. The Ha!Ha! River is long river located in the mountainous and forested area of the Saguenay basin (Quebec), studied from the dam (Ha!Ha! Lake) at PK35.7 to Ha!Ha! Bay (PK0). On Ha!Ha! Lake, a flood event on 19-21 July 1996 led to overtopping and failure of an earth dyke. From the lake to the river mouth, the riverbed was dramatically modified [Brooks et Lawrence, 1999], with huge erosion and deposition, channel widening and changes in river plan form (formation of new channels). Data collected from this event were used during the European project Impact to test sediment transport models on real data [Capart et al., 2007].

The peak water elevation provided by the calculation with sediment transport is generally lower than the one provided by the calculation without sediment transport because the numerical model generally provides erosion. However, Fig. 7 shows that at the downstream end of the river in which huge deposits occurred, the peak water elevation is underestimated by several metres calculating without taking into account the deposits. The cross section shown on Fig. 8 was completely changed during the flood, tremendous bank erosion implying the filling of the main channel with sediments; although the numerical model provides the right trend, it does not include this effect of bank sliding at elevations partly above the peak water elevation.

\section{CONCLUSIONS}

Simulating the wave propagation created by a dam or levee failure requires specific tools to get water depths and velocities in the whole downstream areas. Adapted methods have been developed since the 1990's for both breaching and propagation and became usual methods for engineering purposes. One important step was the development of test cases to be used for validation of software. These latter test cases include analytical solutions, experiments dedicated to dam break wave propagation and breaching as well as field cases related to real dam or levee failures. Uncertainties of engineering studies remain high because often no natural flood reaches such inundation levels, which prevents relevant calibration of the models solving shallow water equations. Thus, in order to limit uncertainty, one should describe and simulate secondary processes such as sediment transport if such processes can influence the results. But sediment transport models are difficult to validate and to calibrate; if changes in topography are large, the complexity stands in the interactions between the sediment fluxes and the bed layers and the corresponding morphological changes. 
Finally, we can conclude that one can be quite confident in hydraulic simulations but the simulation of sediment transport is still a real challenge for the coming years.

\section{REFERENCES}

Asce/Ewri Task Committee On Dam/Levee Breaching (2011) - Earthen Embankment Breaching. J. Hydraul. Eng. ASCE. 137(12) 1549-1564

Ata R., Goutal N. \& Zaoui F. (2010) - Schéma cinétique - Cas Malpasset - HP- 73/2010/007. Technical report, EDF $R \& D$.

Audusse E., Bristeau M.-O. \& Perthame B. (2000) - Kinetic schemes for Saint-Venant equations with source terms on unstructured grids. Technical report 3989. INRIA, Unité de recherché de Rocquencourt, France.

BRIVOIS O. (2005) - Contribution à la modélisation de l'érosion de fortes pentes par un écoulement turbulent diphasique Doctorat discipline Mécanique option Mécanique des fluides, Université Aix-Marseille II. 229 p.

Brooks G. R., \& LAwrence D.E. (1999) - The drainage of the Lake Ha!Ha! reservoir and downstream geomorphic impacts along Ha!Ha! River, Saguenay area, Quebec, Canada. Geomorphology. 28 141-168

Capart H., Spinewine B., Young D. L., Zech Y., Brooks G. R., LeClerc M. \& Secretan Y. (2007) — The 1996 Lake Ha! Ha! breakout flood, Québec: Test data for geomorphic flood routing methods. J. Hydraul. Res. 45 (extra issue): 97109

El Kadi AbderrezzaK K., \& Paquier A. (2009) — One-dimensional numerical modeling of sediment transport and bed deformation in open channels. doi10.1029/2008WR007134. Water Resour Res. 45 W05404

Goutal N.\& Maurel F. (2002) - A finite volume solver for 1D shallow-water equations applied to an actual river. Int. J. Num. Meth. Fl. 38 1-19

Goutal N. \& Maurel F. (1997) - Proceedings of the 2nd workshop on the dam-break wave simulation. Technical report HE-43-097-016, EDF R\&D
Goutal N. \& SAINTE-Marie J. (2010) - A kinetic interpretation of the section-averaged Saint-Venant system for natural river hydraulics. Int. J. Num. Meth. Fl. 67(7) 914-938

Khodashenas S. R. \& Paquier A. (1999) - A geometrical method for computing the distribution of boundary shear stress across irregular straight open channels. J. Hydraul. Res. 37(3) 381-388

PAquier A. (1995) - Modélisation et simulation de la propagation de l'onde de rupture de barrage, Ph D thesis, Université de Saint-Etienne, France.

PAQuier A. (2009) - Rupture d'une digue en milieu fluvial (Agly en 1999). Chapitre 10. In: Tanguy, J. M. (coord.), De la goutte de pluie jusqu'à la mer, traité d'hydraulique environnementale, volume 7, applications des modèles numériques en ingénierie 1, Lavoisier, Paris, France. 7(1) 127-138

PAquiER A. (2015) - Comparison of three methods assessing the inundation caused by the erosion of an embankment. La Houille Blanche 4 32-35

PAQuier A., FANG Z.X. \& Rouch B. (2002) - Hydraulic modelling of the 1999 flood in the lower reach of Agly river. In: Y. Zech (Ed.), River Flow 2002. Université Catholique de Louvain La Neuve, Louvain, Belgium. 247-252

Proceedings Of The First Cadam Workshop Wallingford, United Kingdom (1998)

Proceedings Of The Final Cadam Workshop Zaragoza, Spain (1999)

Soarez Frazao S., Canelas R., Cao Z., Cea L., Chaudhry H.M., Die Moran A., El Kadi K., Ferreira R., Fraga Cadorniga I., Gonzalez Ramirez N., Greco M., Huang W., Imran J. Le Coz J., Marsooli R., Paquier A., Pender G., Pontillo M., Puertas J., Spinewine B., Swartenbroek C., Tsubaki R., Villaret C., Wu W., Yue Z.\& ZeCh Y. (2012) - Dam-break flows over mobile beds: experiments and benchmark tests for numerical models. J. Hydraul. Res. 50 (4) 364-375

Veylon G., Durand E., Sharp M., Simm J., Gaines R., Allsop W., Briggs M., Chasse P., Criado D., Habert J., Morris M., Paquier A., Pullen T., Schwanz N., Serratrice J. F., Smith J., Benahmed N., Bonelli S., Degoutte G., Mercklé S., Philippe P., \& Royet P. (2013) - Chapter 8 Physical processes and tools for levee assessment and design. The International Levee Handbook, London, United Kingdom, CIRIA. 759-988 